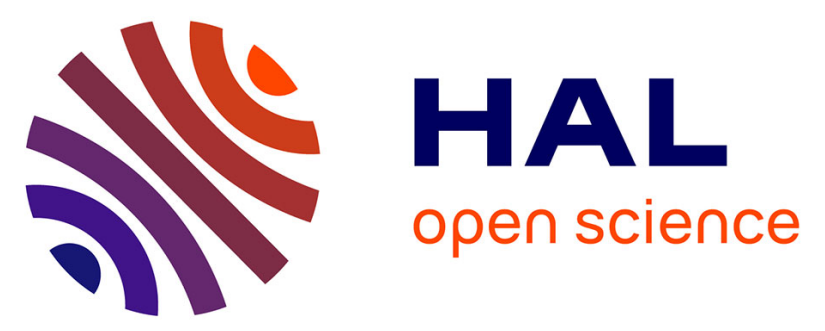

\title{
Changes in some endocrinological and non specific immunological parameters during seawater exposure in the brown trout
}

A.M. Marc, C. Quentel, Armelle Severe, Pierre-Yves Le Bail, Gilles Boeuf

\section{To cite this version:}

A.M. Marc, C. Quentel, Armelle Severe, Pierre-Yves Le Bail, Gilles Boeuf. Changes in some endocrinological and non specific immunological parameters during seawater exposure in the brown trout. Journal of Fish Biology, 1995, 46, pp.1065-1081. 10.1111/j.1095-8649.1995.tb01410.x . hal02714777

\section{HAL Id: hal-02714777 \\ https://hal.inrae.fr/hal-02714777}

Submitted on 1 Jun 2020

HAL is a multi-disciplinary open access archive for the deposit and dissemination of scientific research documents, whether they are published or not. The documents may come from teaching and research institutions in France or abroad, or from public or private research centers.
L'archive ouverte pluridisciplinaire $\mathbf{H A L}$, est destinée au dépôt et à la diffusion de documents scientifiques de niveau recherche, publiés ou non, émanant des établissements d'enseignement et de recherche français ou étrangers, des laboratoires publics ou privés. 


\title{
Changes in some endocrinological and non-specific immunological parameters during seawater exposure in the brown trout
}

\author{
A. M. Marc*, C. Quentel*, A. Severe†, P. Y. Le BaIl $\ddagger$ And G. Boeuf† \\ ${ }^{*}$ CNEVA Laboratoire de Pathologie des Animaux Aquatiques. B. P. 70, 29280 \\ Plouzané, Brest; †IFREMER Laboratoire de Physiologie des Poissons. Centre de Brest, \\ B. P. 70, 29280 Plouzané, Brest; and $\downarrow I N R A$ Laboratoire de Physiologie des Poissons, \\ Campus de Rennes-Beaulieu, 35042 Rennes, France
}

(Received 3 March 1994, Accepted 15 August 1994)

\begin{abstract}
The influence of autumnal progressive and direct seawater transfers on ionic parameters, plasma growth hormone $(\mathrm{GH})$ and thyroid hormones (TH) and also on the non-specific immune traits phagocytic activity, lysozyme and non-specific cytotoxicity were examined in $45-55 \mathrm{~g}$ brown trout (Salmo trutta). In both experiments, the seawater transfer induced the same pattern of endogeneous modifications but they were more pronounced and more lasting after the direct seawater transfer than after the progressive one. In seawater-transferred trout, there was a significant transitory increase of the plasma osmolarity, chloride concentration, $\mathrm{GH}$ levels and a transient decrease of the TH. The phagocytic activity of the pronephric leucocytes and the lysozyme concentrations were significantly higher in seawater-transferred trout than in controls. Nevertheless, the non-specific cytotoxicity should not be modified after the seawater exposure. Moreover significant positive correlations were observed between plasma $\mathrm{GH}$ and chemiluminescence or lysozyme increases. These data support the hypothesis that $\mathrm{GH}$ is involved in the salmonids' non-specific immune potential, especially by stimulating the macrophage functions.
\end{abstract}

Key words: salmonids; Salmo trutta; endocrinology; growth hormone; non-specific immunology; phagocytic activity.

\section{INTRODUCTION}

Salmonids display a variety of patterns in hypo-osmoregulatory abilities. The anadromous salmonid species develop hypo-osmoregulatory capacities with hormonal modifications during the seasonal process of smolting prior to migration to sea water (SW) (Boeuf, 1993), while in non-migratory forms, such as brown trout Salmo trutta Fario, SW tolerance is size-dependent (Dickhoff, 1992). SW transfer induces ionic and osmotic imbalance at first, which is regulated, in a successful transfer, by an increase of the gill (Na-K)-ATPase, secreting excess salts (Boeuf \& Harache, 1982, 1984). Hypo-osmoregulatory ability has been reported to be under endocrine control (Dickhoff, 1992). Indeed, both smolting and entry into SW are accompanied by increases in plasma growth hormone (GH) levels (Boeuf et al., 1989; Sakamoto et al., 1990) and cortisol (Franklin et al., 1992). The thyroid hormones (TH) plasma concentrations are unaffected or decrease after SW transfer (Boeuf \& Le Bail, 1990).

Furthermore, there is growing evidence of a marked interaction between the endocrinology and immunology of mammals (see for review Kelley, 1989; Weigent \& Blalock, 1989). Among other immune influences, pituitary GH has 1065

$0022-1112 / 95 / 061065+17 \$ 08.00 / 0$

(C) 1995 The Fisheries Society of the British Isles 
been reported to stimulate macrophage functions (Kelley, 1989). Similarly, even if the results are more controversial, TH seem to be active on the immunological potential in mammals (Fabris, 1973) and also in birds, among others by enhancing the natural cell mediated cytotoxicity (Haddad \& Marshaly, 1991). In salmonids, relationships between endocrinology and immunology have been observed, especially with cortisol largely described as an immuno-suppressive hormone (Tripp et al., 1987; Pickering et al., 1989). More recently, Kajita et al. (1992) reported that GH stimulated the natural cytotoxicity of the rainbow trout Oncorhynchus mykiss (Walbaum) spleen, blood and head kidney leucocytes. Possible immune modifications could be considerable when fish are confronted with a new and potentially pathogenic microbiological environment in SW. The non-specific immune process, including phagocytose, lysozyme activity and the non-specific (natural) cytotoxicity constitute a significant step of the immune response and is consequently relevant in fish disease resistance.

The purpose of this study was to investigate in brown trout the effects of progressive and direct SW exposure on physiological osmotic and ionic regulation, on endocrine status of $\mathrm{GH}$ and $\mathrm{TH}$ and also on non-specific immunological potential: phagocytose, Iysozyme concentration and natural cytotoxicity. Furthermore, from the results, this study will try to clarify the relationship between some endocrinological and immunological elements in the resident salmonid, the brown trout.

\section{MATERIAL AND METHODS}

\section{FISH AND EXPERIMENTAL PROTOCOL}

Female brown trout, 10 months old, weighing $45-55 \mathrm{~g}$ were obtained from the SEMII hatchery (Le Drennec, Brittany, France) and transferred to the laboratory 2 weeks before the study began.

Two experiments were conducted. For each experiment 360 fish were divided equally between six 100-l tanks (Ewos). Fish were fed to satiety with a commercial pellet (Trouw, Trouvit 2 or $3 \mathrm{~mm}$ ). Temperature and photoperiod were natural throughout the study (see later).

During the first experiment, half of the animals (three tanks) were transferred from fresh water (FW) to SW in two steps: they were transferred directly to a salinity of $29 \pm 1 \%$ during 1 week, and then to $35 \pm 1 \% \%$. The other half of the fish (three tanks) was maintained in FW and used as controls. The experiment began on 26 October and was carried out for 3 months. During this time, the temperature gradually decreased, from $12^{\circ} \mathrm{C}$ in October to $10^{\circ} \mathrm{C}$ in November in FW and from 12 to $10.5^{\circ} \mathrm{C}$ in SW.

The second experiment started on 7 December and was also carried out for 3 months. Half of the fish (three tanks) were transferred directly from FW to $\mathrm{SW}$ at $35 \pm 1 \%$. The others were used as controls and maintained in FW. During this experiment, the temperature decreased from 10 to $5^{\circ} \mathrm{C}$ in $\mathrm{FW}$ and from 10 to $7^{\circ} \mathrm{C}$ in SW.

In both experiments, handling stress was avoided by turning off the FW supply of the tank and turning on the SW supply in the same tank.

\section{SAMPLING}

\section{Timetable}

The fish were sampled 8 days before $($ day -8$)$ the SW transfer, just before on day 0 and $1,2,4,7,21$ and 90 days after the SW transfer. On days 0,1 and 4, four fish were 
sampled in each tank to collect the plasma. On days $-8,2,7,21$ and 90 , six fish were sampled per tank both to harvest plasma and immune organs.

\section{Biometric parameters}

Each sampled fish was measured from the head to the tail-fork and weighed to calculate the condition factor according to the following formula:

$$
K=\left[P(\mathrm{~g}) / L^{3}(\mathrm{~mm})\right] \times 10^{5} .
$$

\section{Blood collection}

Each fish, starved for $24 \mathrm{~h}$, was killed rapidly by a blow to the head and the blood was collected immediately from the caudal vessels by means of a heparinized Vacutainer. Plasma samples were prepared by centrifugation at $2000 \mathrm{~g}$ for $15 \mathrm{~min}$ at $4^{\circ} \mathrm{C}$ and frozen at $-20^{\circ} \mathrm{C}$ in aliquots until analysis. In each type of water, there were 12 samples on days 0,1 and 4 , and 18 samples on days $-8,2,7,21$ and 90 .

\section{Gill samples}

On days 0 and 21 , the gill filaments were removed by dissection, rinsed with $0.25 \mathrm{M}$ sucrose, pH 7.4, and stored rapidly in liquid nitrogen.

\section{Cell preparation procedure of the immune organs}

The head kidney and/or the spleen of six fish, both controls and those transferred to $\mathrm{SW}$, were removed by dissection and used immediately. The cell suspension of each organ was prepared by grinding tissue through a metallic filter (Collector Belco$100 \mu \mathrm{m})$. The cells, which were suspended in Hank's balanced salt solution without phenol red (HBSS) or in RPMI 1640 Dutch modification, according to the studied immunological parameter, were adjusted to the appropriate concentration of viable cells employing a Thoma's haemocytometer by Trypan blue exclusion.

\section{ANALYTICAL PROCEDURE}

\section{Plasma parameters}

Ionic and osmotic parameters. Plasma osmolarity was measured with an Advanced Instrument osmometer (mosmol $1^{-1}$ ) and plasma $\mathrm{Cl}^{-}$, by argentimetric titration with a Radiometer, model CMT 10 (mequiv. 1 $^{-1}$ ).

Endocrinal parameters. Plasma concentrations of tri-iodothyronine $\left(\mathrm{T}_{3}\right)$ and thyroxine $\left(\mathrm{T}_{4}\right)$ were determined by radioimmunoassay (Boeuf \& Prunet, 1985). Plasma growth hormone $(\mathrm{GH})$ levels were measured by specific homologous radioimmunoassay (Le Bail et al., 1991).

Lysozyme assay. Plasma Iysozyme activity was assayed according to the method described by Muona \& Soivio (1992) with modifications. Briefly, the assay is based on the decrease in optical density at $450 \mathrm{~nm}$ of a Micrococcus lysideikticus suspension after incubation for $15 \mathrm{~min}$ with the plasma. For each assay a standard curve was made with lyophilized hen egg white lysozyme (Sigma L-6876). The results are expressed as $\mu \mathrm{g} \mathrm{ml}^{-1}$ equivalent of hen egg white lysozyme activity.

Branchial $\left(\mathrm{Na}^{+}-\mathrm{K}^{+}\right)$-ATPase. Gill $\left(\mathrm{Na}^{+}-\mathrm{K}^{+}\right)$-ATPase was determined according to the method used by Lasserre et al. (1978).

\section{Cellular immunological parameters}

Phagocytic activity measured by chemiluminescence. Chemiluminescence (CL) assay was performed according to the method described by Scott \& Klesius (1981) modified as Obach \& Baudin Laurencin (1992) using opsonized zymosan adjusted to $5 \mathrm{mg} \mathrm{ml}^{-1}$. 
Chemiluminescence was measured at $20^{\circ} \mathrm{C}$ every $5 \mathrm{~min}$ for $20 \mathrm{~min}$ and then, every $10 \mathrm{~min}$ up to 60 min on a 1250 LKB luminometer. Only the maximal values of CL observed during this time were used as results.

Natural cytotoxicity assay. Lymphocyte isolation procedure: the head kidney and splenic cells, suspended in RPMI 1640 supplemented with antibiotics (penicillin $450 \mathrm{U}$ $\mathrm{ml}^{-1}$ and streptomycin $75 \mathrm{mg} \mathrm{ml}^{-1}$ ) and $2 \mathrm{nM}$ of 2 -mercapto-ethanol, were layered on top of a $3 \mathrm{ml}$ Ficoll-plaque (Histopaque-1077, Sigma) and centrifuged at $600 \mathrm{~g}$ for $30 \mathrm{~min}$ at $20^{\circ} \mathrm{C}$. The lymphocytes were collected at the RPMI/Ficoll interface and washed twice. The final lymphocyte suspension was adjusted to $5 \cdot 10^{6}$ viable lymphocytes $\mathrm{ml}^{-1}$ in RPMI 1640 supplemented with $2 \mathrm{~mm}$ L-glutamine and $10 \%$ foetal calf serum.

Cytotoxicity assay: the lymphocytes were used as effector cells and a rainbow trout cell line (RTH, rainbow trout hepatoma, Fryer et al., 1981) were used as target cells. The same volumes of the target cells $\left(5 \cdot 10^{4}\right.$ cells ml $\left.{ }^{-1}\right)$ and effector cells $\left(5 \cdot 10^{6}\right.$ cells $\left.\mathrm{ml}^{-1}\right)$ were added to culture tubes. For each fish organ, the tubes were duplicated. After centrifugation $\left(200 \mathrm{~g}, 5 \mathrm{~min}\right.$ at $20^{\circ} \mathrm{C}$ ), the tubes were incubated $18 \mathrm{~h}$ at $22^{\circ} \mathrm{C}$ in an airtight gas box containing $5 \% \mathrm{CO}_{2}$. Triplicated control tubes without effector cells were prepared at each assay. The percent of cytotoxicity was calculated using the following method:

$$
\% \text { cytotoxicity }=[(A-B) / A] \times 100 \text { (Angelidis, 1987) }
$$

where $A$ is the number of viable RTH cells in controls and $B$ is the number of viable RTH cells in tubes with effectors cells. The number of the viable cells was determined by Trypan blue exclusion employing a Mallassez's haematocytometer.

\section{STATISTICAL ANALYSIS}

Concerning the osmolarity, chloride concentration, plasma TH levels and lysozyme concentration, data were subjected both to Student's test to compare FW and SW trout on the same day, and to one-way analysis of variance (ANOVA) together with Newman-Keuls multiple comparison procedure to assess the significance of a change during the experiment for a given environmental medium.

Plasma GH concentrations and cellular immunological parameters did not follow a normal distribution so the results were subjected to two non-parametric tests, the Mann-Whitney test, which compares FW and the SW transferred trout at the same time and the Kruskall-Wallis test followed by the Dunn test to assess the significance of a change throughout the experiment for a given treatment.

$\left(\mathrm{Na}^{+}-\mathrm{K}^{+}\right)$-ATPase activities and condition factor were submitted to the Student's test to compare both fish.

Linear regressions were used to correlate plasma $\mathrm{GH}$ levels after log transformation with chemiluminescence and lysozyme concentration.

\section{RESULTS}

\section{BIOMETRIC PARAMETERS}

Condition factors (Fig. 1) decreased transitorily after the progressive and direct SW transfers. These decreases which were significant $(P<0.05$ Student's test) on day 1, 2 and 4 after progressive transfer, were more pronounced and more lasting, until day 7 after direct transfer. Moreover, condition factors of the SW transferred trout were significantly lower than those of the controls 90 days after transfer.

\section{IONIC AND OSMOTIC PARAMETERS}

The plasma osmolarity of the trout in FW was between 300 and 320 mosmol $1^{-1}$, for a chloride concentration between 120 and 140 mequiv. $1^{-1}$ (Fig. 2). The 


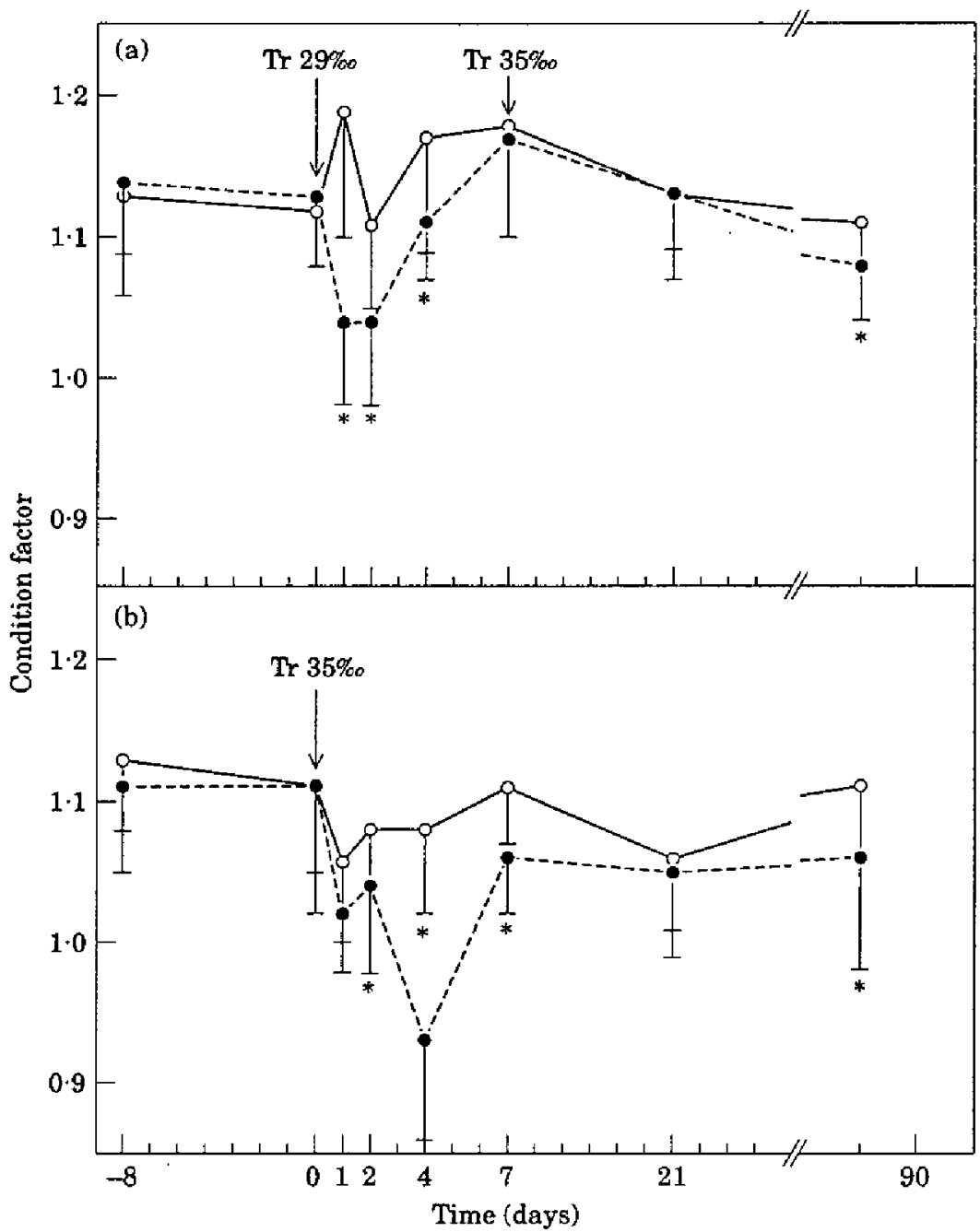

FIG. 1. Condition factor in freshwater-transferred $(O)$ and (a) progressive and (b) direct seawatertransferred trout (-). Each point represents the mean \pm s.E. of 12 or 18 fish. *, Significantly different at $5 \%$ level with the Student's test from corresponding control values.

SW transfer provoked a transient osmotic imbalance depending on the transfer, progressive or direct.

On the first day after the progressive SW transfer, plasma osmolarity and chloride levels increased significantly ( $P<0 \cdot 05$, ANOVA and Student's test), 30\% above $\mathrm{FW}$ values. Levels then decreased but stayed significantly higher than in controls 2 and 4 days after the transfer.

In direct SW transfer, plasma osmolarity and chloride levels rose significantly $(P<0 \cdot 05$, ANOVA and Student's test) from day 1 until day $4,50 \%$ above $\mathrm{FW}$ values, before declining slightly. The osmotic balance was restored 21 days after transfer.

SW transfers, both progressive and direct resulted in a significant increase $\left(P<0.05\right.$, Student's test) of the branchial $\left(\mathrm{Na}^{+}-\mathrm{K}^{+}\right)$-ATPase (Table I). 


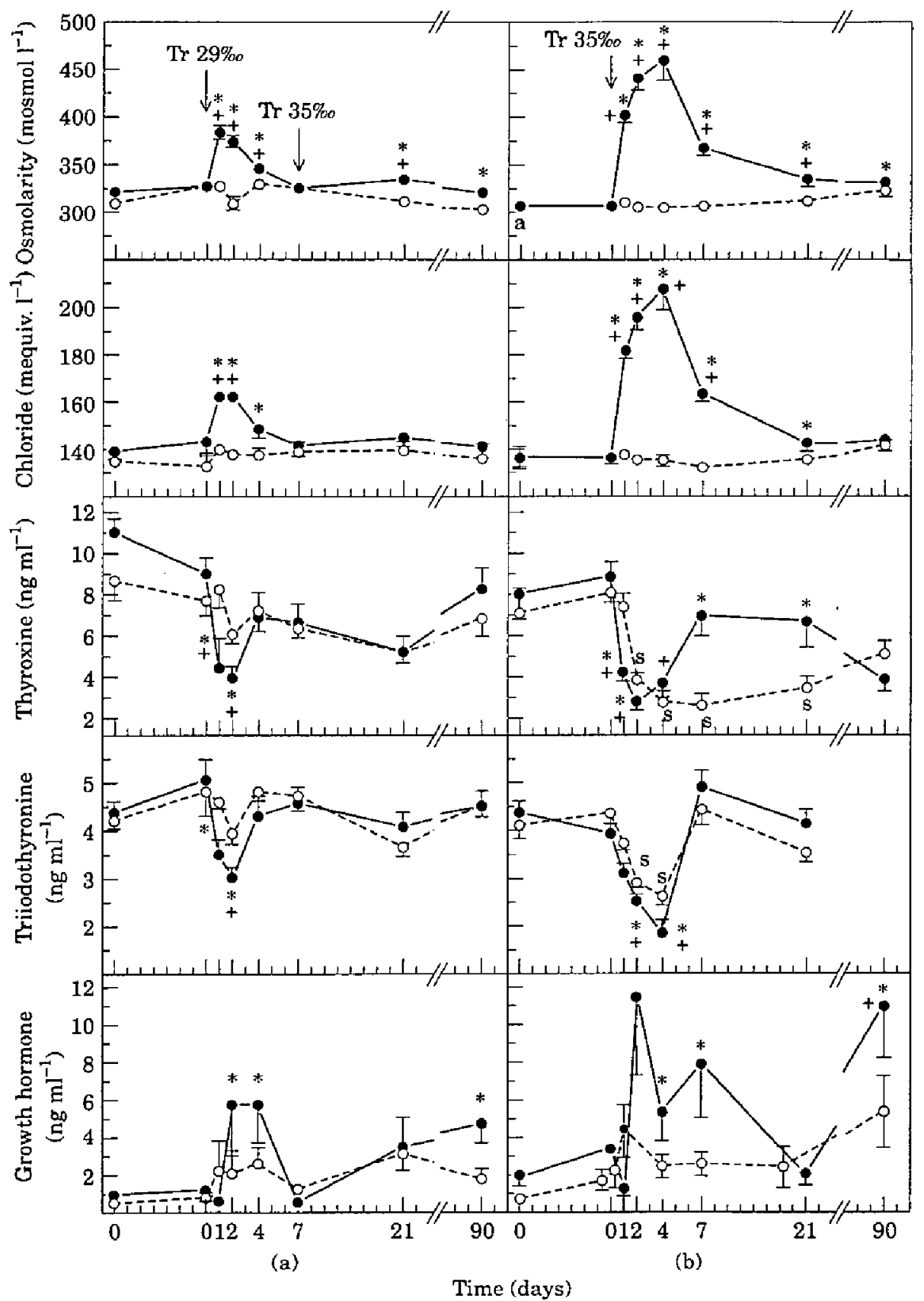

FIG. 2. Plasma osmolarity, chloride concentration, thyroid hormone and growth hormone (GH) in freshwater-transferred (O) and in (a) progressive and (b) dicect seawater- ( $S W$ ) transferred trout (-). Each point represents the mean \pm s.E. of 12 or 18 fish. *. Significantly different from the corresponding control values at $5 \%$ level. Student's test for the all except the GH for which is the Mann-Whitney test. +, Significantly different from the pre-SW values at $5^{\circ} \%$ level. ANOVA Newman-Keuls for all except for the GH for which is the Kruskall-Wallis test followed by the Dunn test. S. Significantly different from the pre-SW time values at $5 \%$ level. ANOVA Newman-Keuls. 
Table I. Mean \pm standard error of gill $\left(\mathrm{Na}^{+}-\mathrm{K}^{+}\right)$-ATPase activity in freshwater- and progressive or direct seawatertransferred trout

\begin{tabular}{|c|c|c|c|c|}
\hline & \multicolumn{2}{|c|}{ Day 0} & \multicolumn{2}{|c|}{ Day 21} \\
\hline & $F W$ & SW & FW & SW \\
\hline Progressive transfer & $\begin{array}{r}4.00 \\
\pm 2.39\end{array}$ & $\begin{array}{r}4.72 \\
\pm 1.95\end{array}$ & $\begin{array}{r}3.87 \\
\pm 2.06\end{array}$ & $\begin{array}{r}29.84 \\
\pm 2.62\end{array}$ \\
\hline Student & \multicolumn{2}{|c|}{ NS } & \multicolumn{2}{|c|}{$\mathrm{s}$} \\
\hline Direct transfer & $\begin{array}{r}3.62 \\
\pm 1.40\end{array}$ & $\begin{array}{r}3 \cdot 50 \\
\pm 1 \cdot 17\end{array}$ & $\begin{array}{r}3.90 \\
\pm 0.73\end{array}$ & $\begin{array}{r}19.39 \\
\pm 1.63\end{array}$ \\
\hline Student & \multicolumn{2}{|c|}{ NS } & \multicolumn{2}{|c|}{$\mathrm{s}$} \\
\hline
\end{tabular}

s or NS, Significance at $5 \%$ level using Student's test between the seawatertransferred trout and the corresponding controls.

\section{ENDOCRINOLOGY}

\section{Thyroid hormones ( $T H$ )}

During the first $24 \mathrm{~h}$ of the SW transfer, a transitory drop appeared in plasma concentration of the TH (Fig. 2).

$\mathrm{T}_{3}$ circulating levels of SW transferred fish decreased slightly but significantly $(P<0.05$, ANOVA and Student's test $), 1 \quad(P<0.05$ Student's test only) and 2 days after the progressive transfer and 2 and 4 days after the direct one. Then, $T_{3}$ levels rose until reaching the level of plasma concentrations of the FW fish.

Moreover, there was a transient and significant drop $(P<0.05$, ANOVA and Student's test) in the $T_{4}$ levels 1 and 2 days after progressive and direct transfers remaining until day $4(P<0 \cdot 05$, ANOVA) after direct transfer (Fig. 2). However, during the second experiment, TH plasma concentrations of controls decreased significantly $\left(P<0.05\right.$, ANOVA) on days 2 and 4 for $T_{3}$, and on days 2 until 21 for $T_{4}$.

\section{Growth hormone (GH)}

The transfer to a hyperosmotic environment induced a transitory increase of the GH plasma levels which was more marked and more lasting after direct transfer (Fig. 2). GH concentrations rose from day 2 after the progressive transfer and remained significantly $(P<0.05$, Mann-Whitney test) higher than the controls until 4 days after transfer. For the direct transfer, GH levels increased on day 2 to $11 \mathrm{ng} \mathrm{ml} \mathrm{g}^{-1}$ and even if they decreased, they remained significantly higher $(P<0.05$, Mann-Whitney test) than the FW trout on days 4 and 7. Then, the circulating levels of GH decreased markedly 7 days after progressive transfer and 21 days after direct transfer. Three months after the SW transfers, in both experiments, plasma GH concentrations of the transferred fish were significantly higher $(P<0.05$, Mann-Whitney test) than those of the controls. 


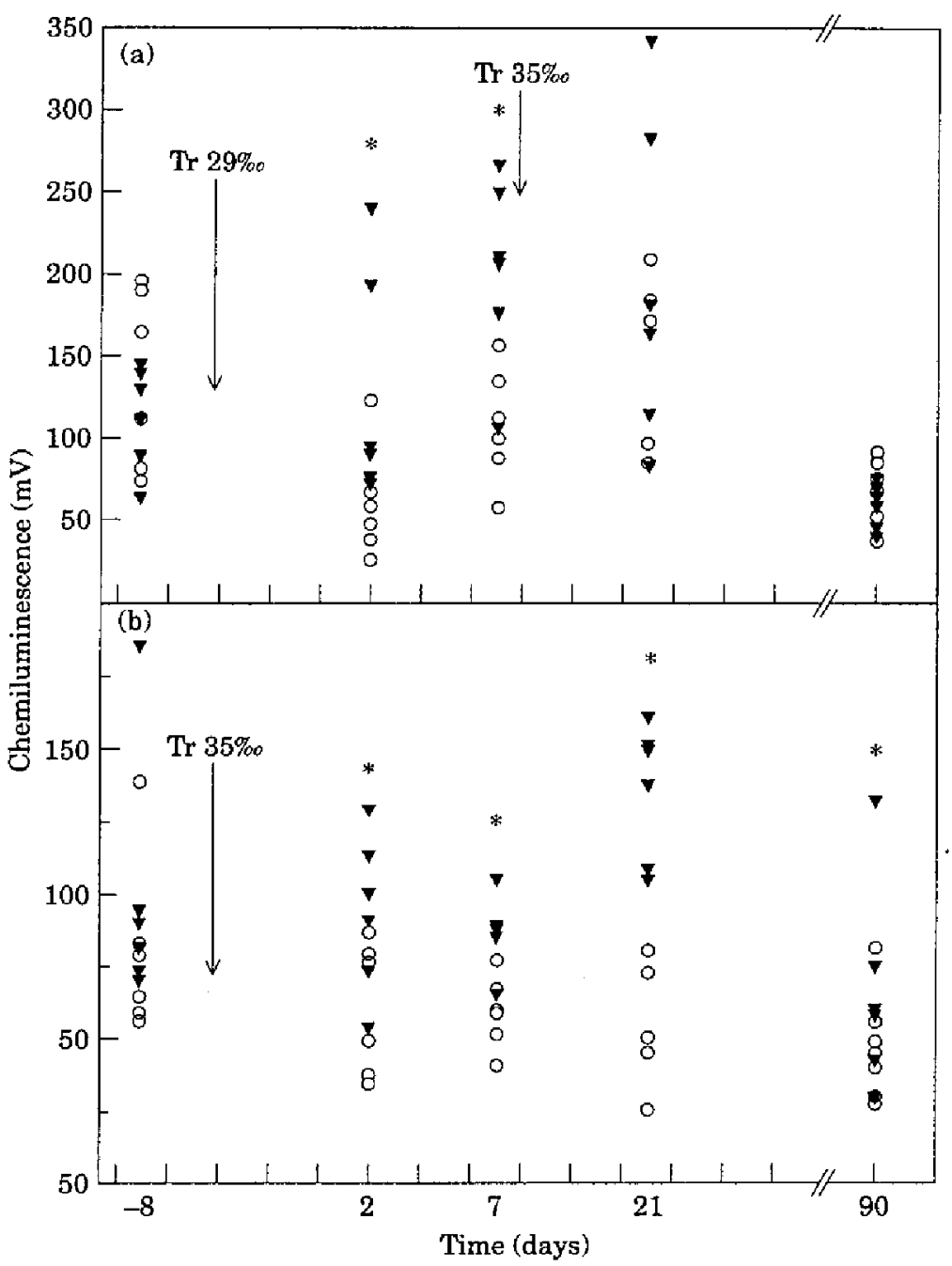

FIG. 3. Maximal individual values of the chemiluminescence of the head kidney leucocytes in freshwater-transferred (O) and (a) progressive or (b) direct seawater- (SW) transferred trout ( $\mathbf{V}$ ). *, Significantly different from the corresponding control values at $5 \%$ level. Mann-Whitney test.

FW trout GH concentrations increased weakly and not significantly from day 1 until day 4 in the first experiment and on day 2 in the second.

\section{IMMUNOLOGICAL PARAMETERS}

\section{Phagocytic activity measured by chemiluminescence}

A large variation in the maximal individual values of the $C L$ response was observed between fish in the same sample and between the days of experimentation, which was inherent to the technique. However, the statistical comparison of the maximal individual values by the Mann-Whitney test showed that the CL of the SW transferred fish was significantly higher $(P<0 \cdot 05)$ than that of the controls 2 and 7 days after the progressive transfer and also 2, 7, 21 and 90 days after the direct one. 


\section{Natural cytotoxicity}

The intensity of the response varied widely between fish belonging to the same tank and between the tanks. In both experiments and organs, the lysis percentages of the RTH cells were similar, between 15 and $30 \%$ (Table II).

The SW transfer did not modify the non-specific cytotoxicity. Only the cytotoxicity of the splenic lymphocytes of the direct transferred trout appeared significantly higher $(P<0.05$, Mann-Whitney test) than in the controls on day 21 .

\section{Plasma lysozyme concentration}

In the first experiment, the plasma lysozyme concentrations were not determined until day 4 after the SW transfer because of a technical problem.

In both SW transfers, the plasma lysozyme concentration was higher in the transferred trout than in the controls (Fig. 4). The lysozyme concentrations of the SW transferred fish were significantly higher $(P<0.05$, Student's test) than the controls 7,21 and 90 days after progressive transfer and 1, 4, 7,21 and 90 days after direct transfer. Maximal concentrations were observed on day 21 in the first experiment and on day 4 in the second. Whatever the SW transfer, the lysozyme concentrations in the $\mathrm{SW}$ transferred trout increased significantly $(P<0.05$, ANOVA), on day 21 for the progressive transfer and from day 4 until day 21 for the direct transfer.

\section{LINEAR REGRESSIONS}

The linear regressions between the individual values of $\mathrm{GH}$ and $\mathrm{CL}$ or lysozyme concentrations were carried out only when both the $\mathrm{GH}$ and the $\mathrm{CL}$ or lysozyme concentrations were significantly higher in SW transferred trout than in controls. Then, as a result a significant $(P<0.05)$ positive correlation was found between the GH (log-transformed) and the CL individual values on day 2 after the progressive transfer [Fig. 5(a)] and on days 2 and 7 after the direct one [Fig. $5(b)$, (c)]. Another significant $(P<0.05)$ positive correlation was observed between plasma GH (log-transformed) and lysozyme concentrations on days 4 and 7 after the direct transfer [Fig. 5(d), (e)].

\section{DISCUSSION}

Boeuf \& Harache $(1982,1984)$ and Almendras et al. (1993), observed a serious osmotic imbalance during the SW transfer of resident brown trout. The intensity of this disequilibrium depends on the method of SW transfer; it was less marked during progressive transfer, than during direct transfer. Therefore, a progressive SW transfer improves the 'quality' of the adaptation to the marine environment.

Branchial (Na-K)-ATPase activity is often used as an index of the hypoosmoregulatory status, particularly for the smolting species (Dickhoff, 1992), and it is normally higher in SW than in FW teleosts. In the present study, the (Na-K)-ATPase activities of between 3 and $4 \mu \mathrm{mol} \mathrm{Pi} \mathrm{mg} \mathrm{protein}{ }^{-1} \mathrm{~h}^{-1}$ detected in $\mathrm{FW}$ fish were comparable with the observations made in sedentary species, about $5 \mu \mathrm{mol} P i \mathrm{mg}$ protein ${ }^{-1} \mathrm{~h}^{-1}$ (Boeuf \& Harache, 1984). The significant increase in the (Na-K)-ATPase activity observed 3 weeks after each transfer allowed the fish to establish electrolytic homeostasis after SW entry. 


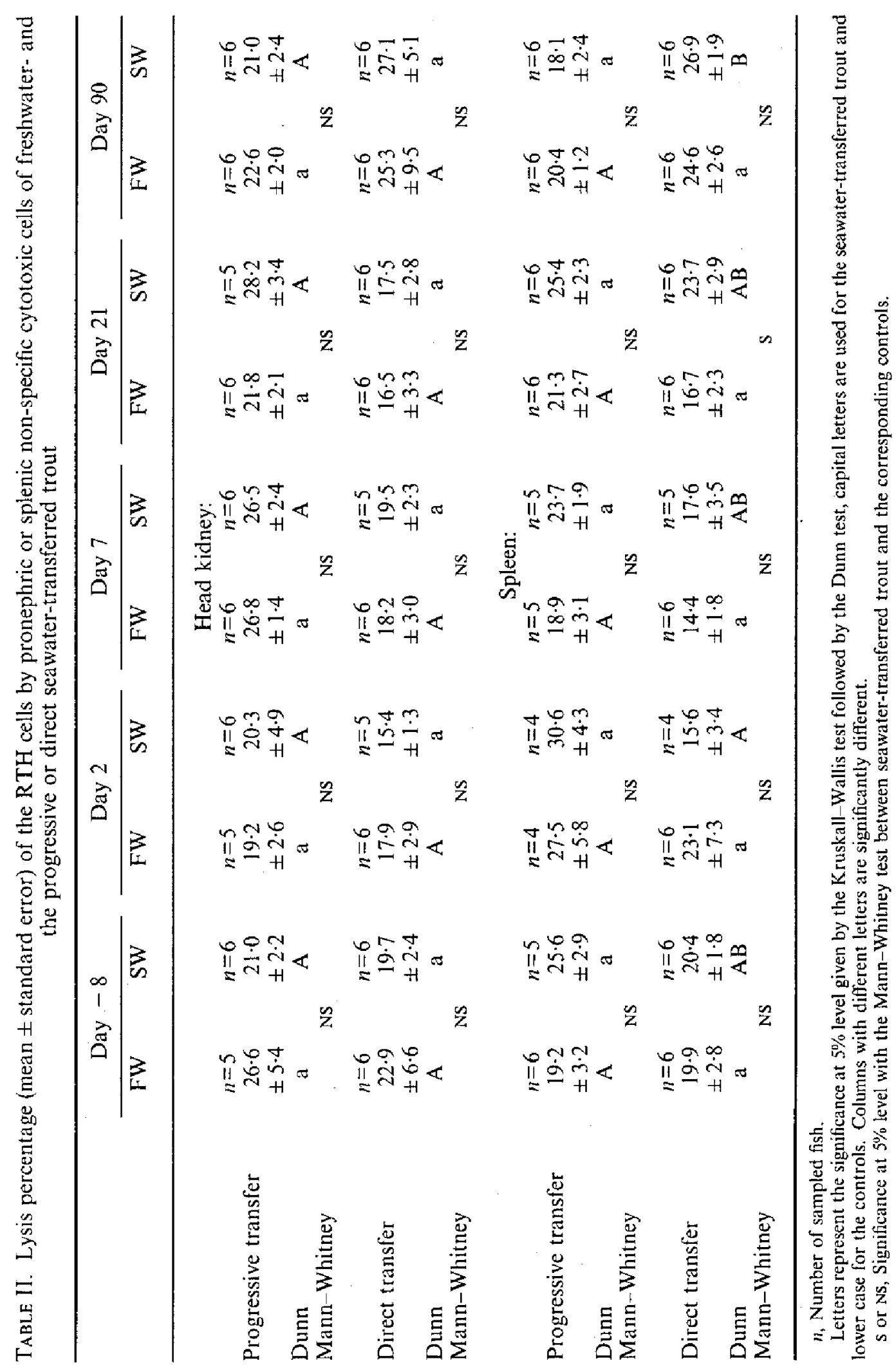




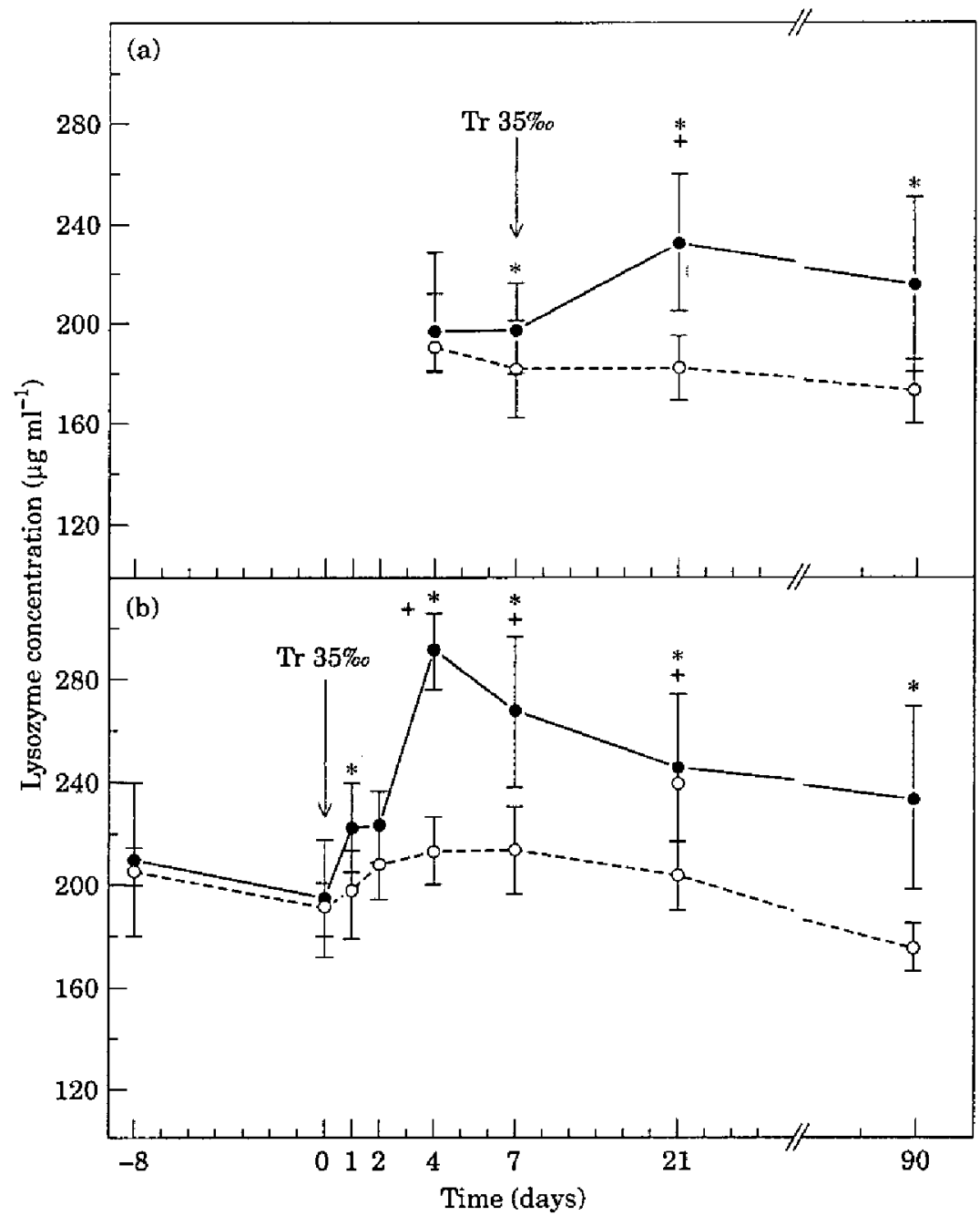

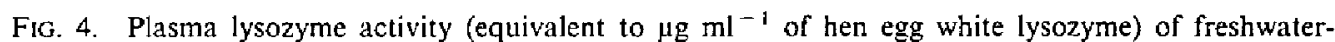
transferred (O) and (a) progressive or (b) direct seawater- (SW) adapted trout $(\bullet)$ ) ${ }^{*}$, Significantly different from the corresponding control values at $5 \%$ level by the Student's test. +, Significantly different from the pre-SW values at $\$ \%$ level by ANOVA Newman-Keuls.

Several authors reported that (Na-K)-ATPase increase observed after SW transfer is accompanied by endocrine changes, among others, an elevation of plasma GH as observed Boeuf et al. (1989) and Collie et al. (1989) in anadromous salmonids and Sakamoto et al. (1990) in rainbow trout. In brown trout, the plasma GH levels were modified significantly by environmental salinity. Furthermore, adaptation to a hyperosmotic environment with stimulation of the gill (Na-K)-ATPase in non-smolting species has been observed after administration of GH (Bolton et al., 1987; Almendras et al., 1993). This GH action on the gill (Na-K)-ATPase might be mediated by GH specific receptors, already shown by Fryer \& Bern (1979) and Sakamoto \& Hirano (1991) in salmonid gills.

After this transitory increase $\mathrm{GH}$ concentrations returned to a level close to the initial FW concentration. This is consistent with the results obtained by 

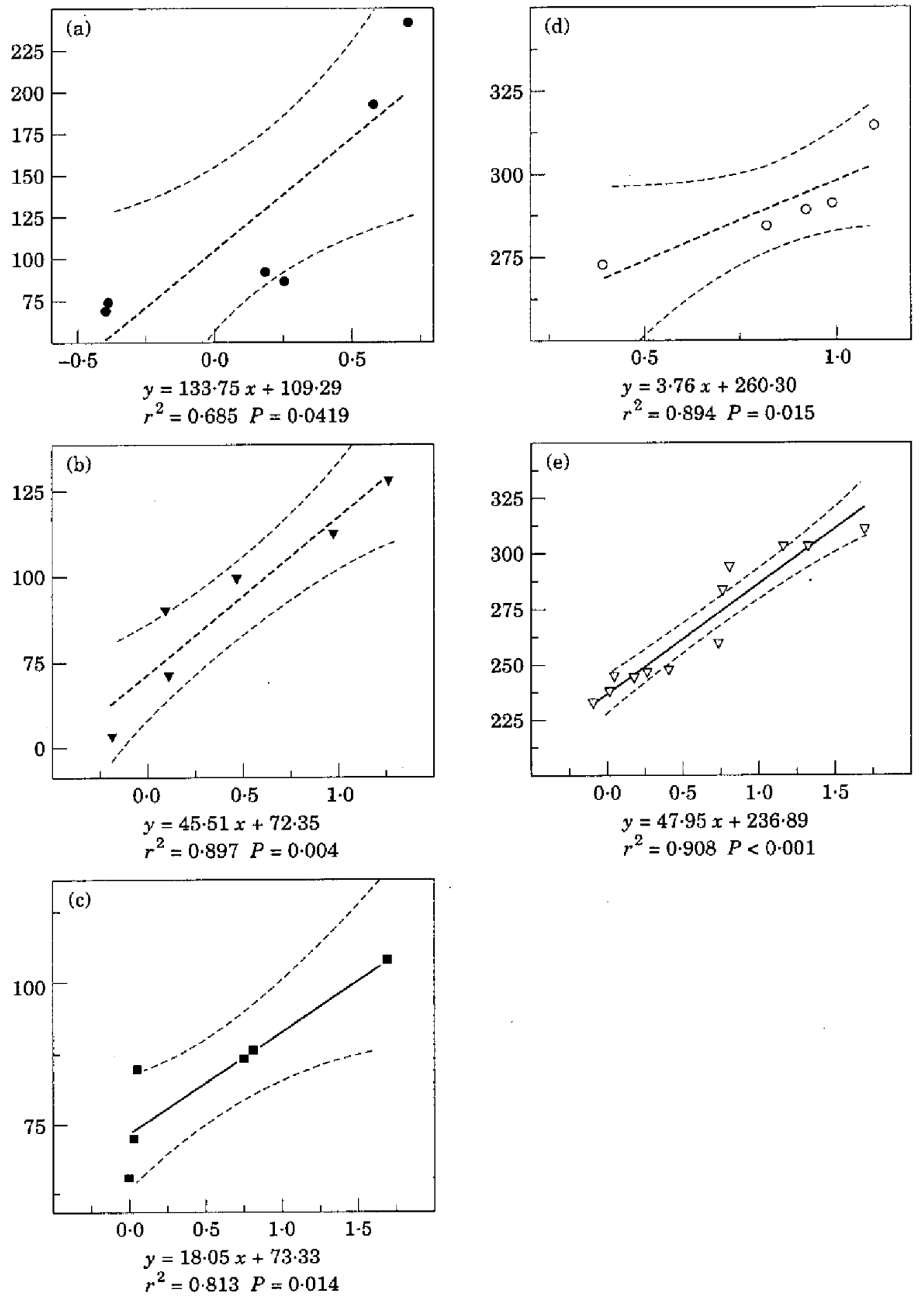

Fic. 5. Linear regressions between the log of $\mathrm{GH}$ concentration and the chemiluminescence. (a) On day 2 after progressive transfer ( ): (b) on day 2 after direct transfer ( $\mathbf{\nabla}$ ); (c) on day 7 after direct transfer ( $\mathbf{D}$ ). Linear regressions between the log of GH concentration and the lysozyme (d) on day 4 after the direct transfer $(O)$ and (e) on day 7 after the direct transfer $(\nabla)$. (a)-(c) $y=$ Chemiluminescence $(\mathrm{mV}) ; x=\log$ Growth Hormone (ng ml ${ }^{-1}$ ). (d), (e) $y=$ Lysozyme $\left(\mu \mathrm{g} \mathrm{ml}^{-1}\right) ; x=\log$ Growth Hormone (ng ml ${ }^{-1}$ ). 
Sakamoto et al. (1990) and Sakamoto \& Hirano (1991) after rainbow trout transfer to 75 or $80 \%$ sea water. According to these authors, two major factors, regulation of the GH secretion from the pituitary by feedback controls and increased in the plasma metabolic clearance may regulate the plasma $\mathrm{GH}$ levels.

GH concentrations observed in trout 90 days after transfer, were significantly higher than in FW trout. In SW trout, the condition factor was significantly lower than in FW trout, possibly because food intake was reduced as noted by Fauré (1991) in other experiments. Furthermore, Sumpter et al. (1991) established that starvation induced $\mathrm{GH}$ level increases in rainbow trout.

After $\mathrm{SW}$ transfers, plasma $\mathrm{T}_{3}$ and $\mathrm{T}_{4}$ were temporarily and significantly decreased. The weak drop observed in the present study is consistent with the results obtained by Boeuf et al. (1989) in Atlantic salmon Salmo salar L., after autumn transfer and Lebel \& Leloup (1992) in brown trout. After this decrease, plasma TH levels reached concentrations close to the initial FW levels, probably due to the activation of the thyroid through a variety of feedback loops.

In FW fish TH and GH levels followed those of the SW transferred fish but the changes were not significant compared to the pre-SW transfer time, except for TH during the second experiment. The frequent coming and going in the stock farming hall due to the numerous sampling during the first days after the transfers might have induced a chronic stress causing a weak rise of GH levels and a drop in TH concentrations (Pickering, 1993). During the second experiment, the FW temperatures fell to $5^{\circ} \mathrm{C}$ which might be a reason for the significant drop observed in the $\mathrm{T}_{4}$ concentration in FW fish until day 21 (Eales \& Shostak, 1986).

The endocrinological modifications observed during SW adaptation of brown trout in this study, particularly in GH, could have influenced the brown trout immunological potential, as demonstrated by several studies in mammals (Berczi, 1989; Kelley, 1989; Weigent \& Blalock, 1989).

In non-specific immunity, especially in phagocytic cells, the chemiluminescence of the pronephric leucocytes was higher in SW transferred trout whatever the method of transfer, progressive or direct. However, this increase was significant regardless of the day of sampling after direct transfer, and only on days 2 and 7 after the progressive one. Thus, some similarities appear between the increases of the phagocytic activity and those of the plasma GH levels. Indeed, both of them were higher and more lasting after direct transfer and a positive correlation has been observed between both these parameters. These results were in agreement with the observation of Sakai et al. (1991) who noticed that injection of recombinant chum salmon Oncorhynchus keta (Walbaum) GH enhanced the $\mathrm{CL}$ of the pronephric leucocytes of rainbow trout. Furthermore, this phenomenon seems to corroborate the observations made in mammals by Edwards et al. (1988) who noted, after in vivo and in vitro treatment with native or recombinant porcine $\mathrm{GH}$, an increase of superoxide anion production during the phagocytose by rat zymosan-stimulated macrophages. According to Kelley (1989), GH could be 'a newly defined macrophage activiting factor'.

The plasma lysozyme, which is probably mainly produced by the phagocytic cells (Murray \& Fletcher, 1976), was also higher in SW transferred trout than in controls. As for $\mathrm{CL}$, this increase was more pronounced after direct transfer and a significant positive correlation existed between plasma levels of $\mathrm{GH}$ and 
lysozyme 4 and 7 days after direct transfer. This result might be due to the $\mathrm{GH}$ which could affect the brown trout phagocytic cells enhancing the release of lysozyme. Indeed, in humans, GH injections enhanced the lysozomal activity of the polymorphonuclear leucocytes of both hypopituitary dwarfs and normal subjects (Rovensky et al., 1985).

In the present study, an additional non-specific immunological function was studied, the natural cytotoxicity effected by the non-specific cells (NCC). In mammals, Saxena et al. (1982) with mice, and Davila et al. (1987) with rats, have demonstrated that $\mathrm{GH}$ enhances the natural cytotoxicity of peripheral blood or splenic cells. Haddad \& Mashaly (1991) had the same results in chickens. More recently, Kajita et al. (1992) increased the natural cytotoxicity of rainbow trout spleen, kidney and blood leucocytes after a chum salmon recombinant GH injection. In the present study, the control lysis percentages of the RTH cells, between 15-30\%, seemed higher than the 14-15\% observed by Kajita et al. (1992). The different target cells used, RTH in this study and a mouse cell line (P-815) by Kajita et al. (1992), might explain this difference. However, the splenic leucocyte natural cytotoxicity was significantly higher in the direct transferred trout than in the controls, on day 21 only. Therefore, it seems that the natural cytotoxicity was not affected by the SW transfers despite the $\mathrm{GH}$ level changes. However, unlike Kajita et al. (1992), who injected recombinant GH $\left(0.1 \mathrm{ml}\right.$ of a solution at $\left.10 \mu \mathrm{g} \mathrm{ml}{ }^{-1}\right)$, the GH level modifications observed in the present study were endogeneous and probably weaker than those observed by these authors, which could explain the lack of natural cytotoxicity stimulation. On the other hand, it is possible that another phenomenon could mask an eventual stimulation induced by GH, a temporary drop in TH concentrations. Indeed, some studies have shown that the administration of $\mathrm{TH}$ enhanced natural cytotoxicity. Sharma et al. (1982) reported that an exogeneous administration of $\mathrm{T}_{4}$ increased both in vitro and in vivo the splenic and peritoneal natural killer (NK) cell activity in some mice, depending on the strain. Haddad \& Mashaly (1991) observed that $\mathrm{T}_{3}$ could act with $\mathrm{GH}$ to increase chicken natural cell-mediated cytotoxicity.

Other authors have found that high levels of TH, either endogeneous (Grave's disease) or exogeneous (injection in mice and humans) reduced the activity of the NK celis (Papic et al., 1987; Stein-Streilein et al., 1987). Further studies should be carried out to determine the effect of the TH on natural salmonid cytotoxicity.

In conclusion, SW transfer induced endocrinological and immunological modifications in resident brown trout. Some similarities and also positive correlations were observed between $\mathrm{GH}$, phagocytose and plasma lysozyme concentration increases which suggested that among the endocrine changes, $\mathrm{GH}$ plays a significant part on the immune competences especially by enhancing the macrophage functions. Further studies are now being conducted on brown trout, in FW and during SW adaptation, to determine the direct effects of GH administration in vivo on the immune potential. The results will be presented in a future paper.

This research was supported by grants from the National Veterinary and Food Research Centre, 22, rue Pierre-Curie, France. We thank A. Leroux and J. Jeffroy for their excellent technical assistance. 


\section{References}

Almendras, I. M. E., Prunet, P. \& Boeuf, G. (1993). Response in non-migratory stock of brown trout, Salmo trutla, to ovine growth hormone treatment and seawater exposure. Aquaculture 114, 169-179.

Angelidis, P. (1987). Eléments du système immunitaire du bar (Dicentrarchus labrax) et al truite (Salmo gairdneri). Thèse de troisième cycle, Université de Bretagne Occidentale, Brest, France.

Berczi, I. (1989). Immunoregulation by neuroendocrine factors. Developmental and Comparative Immunology 13, 329-341.

Boeuf, G. (1993). Seawater adaptation strategies in salmonids. In Coastal and Estuarine Studies, 43. Aquaculture: Fundamental and Applied Research (Lahlan, B., Vitiello, P., eds). Washington: American Geophysical Union.

Boeuf, G. \& Harache, Y. (1982). Criteria for the adaptation of salmonids to high salinity water in France. Aquaculiture 28, 163-176.

Boeuf, G. \& Harache, Y. (1984). Adaptation osmotique à l'eau de mer de différentes espèces (Salmo trutta, Salmo gairdneri, Salvelinus fontinalis) et hybride (Salmo trutta femelle $\times$ Salvelinus fontinalis mâle) de salmonidés. Aquaculture 40 , $343-358$.

Boeuf, G. \& Le Bail, P. Y. (1990). Growth hormone and thyroid hormones levels during smolting in different populations of Atlantic salmon. In Progress in Comparative Endocrinology 342, 193-197.

Boeuf, G. \& Prunet, P. (1985). Measurements of gill $\left(\mathrm{Na}^{+}-\mathrm{K}^{+}\right)$-ATPase activity and plasma thyroid hormones during smoltification in Atlantic salmon (Salmo salar L.). Aquaculture 45, 111-119.

Boeuf, G., Le Bail, P. Y. \& Prunet, P. (1989). Growth hormone and thyroid hormones during Atlantic salmon, Salmo salar L., smolting, and after transfer to seawater. Aquaculture 82, 257-268.

Bolton, J. P., Collie, N. L., Kawauchi, H. \& Hirano, T. S. (1987). Osmoregulatory actions of growth hormone in rainbow trout (Salmo gairdneri). Joumal of Endocrinology 112, 63-68.

Collie, N. L., Bolton, J. P., Kawauchi, H. \& Hirano, T. (1989). Survival of salmonids in seawater and the time-frame of growth hormone action. Fish Physiology and Biochemistry 7, 315-321.

Davila, D. R., Brief, S., Simon, J., Hammer, R. E., Brinster, R. L. \& Kelley, K. W. (1987). Role of growth hormone in regulating T-dependent immune events in aged, nude, and transgenic rodents. Journal of Neuroscience Research 18, $108-116$.

Dickhoff, W. W. (1992). Seawater adaptation. In Recent Advances in Aquaculture IV Section I.4, Part D (Muir, J. F. \& Roberts, R. J., eds), pp. 152-192. Oxford: Blackwell Scientific Publications.

Eales, J. G. \& Shostak, S. (1986). Influences of temperature and $\mathrm{pH}$ on free $\mathrm{T}_{4}$ and free $\mathrm{T}_{3}$ in charr and trout plasma, General and Comparative Endocrinology 61, $272-277$.

Edwards, C. K., Ghiasuddin, S. M., Schepper, J. M., Yunger, L. M. \& Kelley, K. W. (1988). A newly defined property of somatotropin: priming of macrophages for production of superoxide anion. Science 239, 769-771.

Fabris, N. (1973). Immunodepression in thyroid deprived animals. Clinical and Experimental Immunology 15, 601-611.

Fauré, A. (1991). La truite fario, vers une filière salmonicole marine à la française? Aqua Revue 35, 7-13.

Franklin, C. E., Forster, M. E. \& Davison, W. (1992). Plasma cortisol and osmoregulatory changes in sockeye salmon transferred to sea water: Comparison between successful and unsuccessful adaptation. Journal of Fish Biology 41, $113-122$.

Fryer, J. L., Mc Cain, B. B. \& Leong, J. C. (1981). A cell line derived from rainbow trout (Salmo gairdineri) hepatoma. Fish Pathology 15, 193. 
Fryer, J. N. \& Bern, H. A. (1979). Growth hormone binding to tissues of normal and stunted juvenile coho salmon Oncorhynchus kistutch. Journal of Fish Biology 15, $527-533$.

Haddad, E. E. \& Mashaly, M. M. (1991). Chicken growth hormone, triiodothyronine and thyrotropin releasing hormone modulation of the levels of chickens natural cell-mediated cytotoxicity. Developmental and Comparative Immunology 15, 65-71.

Kajita, Y., Sakai, M., Kobayashi, M. \& Kawauchi, H. (1992). Enhancement of non-specific cytotoxic activity of leucocytes in rainbow trout Oncorhynchus mykiss injected with growth hormone. Fish and Shellfish Immunology 2, 155-157.

Kelley, K. W. (1989). Growth hormone, lymphocytes and macrophages. Biochemical Pharmacology 38, 705-713.

Lasserre, P., Boeuf, G. \& Harache, Y. (1978). Osmotic adaptation of Oncorhynchus kisutch Walbaum. I. Seasonal variations of gill $\mathrm{Na}^{+}-\mathrm{K}^{+}$-ATPase activity in salmon, $0^{+}$-age and yearling, reared in freshwater. Aquaculture 14, 365-382.

Le Bail, P. Y., Sumpter, J. P., Carragher, J. F., Mourot, B., Niu, P. D. \& Weil, C. (1991). Development and validation of a highly sensitive radioimmunoassay for chinook salmon, Oncorhynchus tshawystscha growth hormone. General and Comparative Endocrinology 83, 75-85:

Lebel, J. M. \& Leloup, J. (1992). La triiodothyronine est nécessaire à l'acclimatation à l'eau de mer de la truite fario (Salmo trutta) ou arc en ciel (Oncorhynchus mykiss). Comptes Rendus de l'Académie des Sciences, Paris 314, Série III, 461-468.

Madsen, S. S. \& Naamansen, E. T. (1989). Plasma ionic regulation and gill $\mathrm{Na}^{+} / \mathrm{K}^{+}$. ATPase changes during rapid transfer to sea water of yearling rainbow trout, Salmo gairdneri: time course and seasonal variation. Journal of Fish Biology 34, $829-840$.

Muona, M. \& Soivio, A. (1992). Changes in plasma lysozyme and blood leucocyte levels of hatchery-reared Atlantic salmon (Salmo salar L.) and sea trout (Salmo trutta L.) during parr-smolt transformation. Aquaculture 106, 75-87.

Murray, C. K. \& Fletcher, T. C. (1976). The immunohistochemical localization of jysozyme in plaice (Pleuronectes platessa L.) tissues. Journal of Fish Biology 9 , $329-334$.

Obach, A. \& Baudin Laurencin, F. (1992). Effect of dietary oxidized fish oil and deficiency of anti-oxidants on the immune response of turbot, Scophthalamus maximis. Aquaculture 107, 221-228.

Papic, M., Stein-Streilein, J., Zakarija, M., McKenzie, J. M., Guffee, J. \& Fletcher, M. A. (1987). Suppression of peripheral blood natural killer cell activity by excess thyroid hormone. Journal of Clinical Investigations 79, 404-408.

Pickering, A. D. (1993). Growth and stress in fish production. Aquaculture 111, 51-63.

Pickering, A. D., Pottinger, T. G. \& Carragher, J. F. (1989). Differences in the sensitivity of brown trout, Salmo trutta L., and rainbow trout Salmo gairdneri Richardson, to physiological dosages of cortisol. Journal of Fish Biology 34, 757-768.

Peters, G., Nubgen, A., Raabe, A. \& Mock, A. (1991). Social stress induces structural and functional alterations of phagocytes in rainbow trout (Oncorhynchus mykiss). Fish and Shellfish Immunology 1, 17-31.

Rovensky, J., Ferencikova, J., Vigas, M. \& Lukac, P. (1985). Effect of growth hormone on the activity of some lysosomal enzymes in neutrophilic polymorphonuclear leucocytes of hypopituitary dwarfs. International Journal of Tissues Reactivity VII, $153-159$.

Sakai, M., Kobayashi, M. \& Kawauchi, K. (1991). Enhancement of chemiluminescence response of leucocytes in growth hormone injected rainbow trout, Oncorhynchus mykiss. Developmental and Comparative Immunology 15 (Suppl. 1), S86.

Sakamoto, T, \& Hirano, T. (1991). Growth hormone receptors in the liver and osmoregulatory organs of rainbow trout: Characterization and dynamics during adaptation to seawater. Journal of Endocrinology 130, 425-433.

Sakamoto, T., Ogasawara, T. \& Hirano, T. (1990). Growth hormone kinetics during adaptation to a hyperosmotic environment in rainbow trout. Joumal of Comparative Physiology B160, 1-6. 
Saxena, Q. B., Saxena, R. K. \& Adler, W. H. (1982). Regulation of natural killer activity in vivo. III. Effect of hypophysectomy and growth hormone treatment on the natural killer activity of the mouse spleen cell population. International Archives in Allergy and Applied Immumology 67, 169-174.

Scott, A. L. \& Klesius, P. H. (1981). Chemiluminescence: a novel analysis of phagocytosis in fish. Developments in Biological Standardization 49, 243-254.

Sharma, S. D., Tsai, V. \& Proffit, M. R. (1982). Enhancement of mouse natural killer cell activity by thyroxine. Cellular Immunology 73, 83-97.

Stein-Streilein, J., Zakarija, M., Papic, M. \& McKenzie, J. M. (1987). Hyperthyroxinemic mice have reduced natural killer cell activity. Evidence for a defective trigger mechanism. Journal of Immunology 139, 2502-2507.

Sumpter, J. P., Le Bail, P. Y., Pickering, A. D., Pottinger, T. G. \& Carragher, J. F. (1991). The effect of starvation on growth and plasma growth hormone concentrations of rainbow trout, Oncorhynchus mykiss. General and Comparative Endocrinology 83, 94-102.

Tripp, R. A., Maule, A. G., Schreck, C. B. \& Kaattari, S. L. (1987). Cortisol mediated suppression of salmonid lymphocytes in vitro. Developmental and Comparative Immunology 11, 565-576.

Weigent, D. A. \& Blalock, J. E. (1989). Structural and functional relationships between the immune and neuroendocrine systems. Bulletins de l'Institut Pasteur 87, 61-92. 